\title{
On the Importance of Literary Self-cultivation for Talent Cultivation of Art Design Specialty
}

\author{
Li Minyan ${ }^{1,}$ a, Li Minfang ${ }^{1, b}$ \\ ${ }^{1}$ Jiangxi Science \& Technology Normal University, Nanchang, Jiangxi, 330013, China \\ a724390219@qq.com, b63910546@qq.com
}

Keywords: art design; literary accomplishment; aesthetic; quality;

\begin{abstract}
Students of art design generally lack literary training, and literary cultivation is very important for cultivating high-quality art design professionals. This paper analyzes the reasons why students of art design majors lack literary training and proposes corresponding solutions.
\end{abstract}

\section{Introduction}

Art and design is a conscious and creative activity in the history of human development. It is a comprehensive carrier that integrates literature, art and other aspects. The establishment of art design can promote students in science and technology to achieve mutual integration, comprehensive design concept of innovation. In order to deepen students 'accomplishment, the majority of art and design educators need to improve the students' literary accomplishment, with high-quality art design education as the basis of development, combine the theory and practice together to create a technical and innovative Development environment, so that students' learning ability, professional skills have been significantly improved.

\section{The Development of Art Design Education}

Under the current situation, with the development of art and design in China, the number of students who graduated from art colleges is increasing every year. According to the national education website statistics show that, as of 2013, in 2101 of the national higher art institutions, there are 1010 schools established art professional and faculties. Under the background of globalization, contemporary art students are prevalent in the contradictions and conflicts brought by the diversified culture. "Art test hot" phenomenon also prompted the relevant institutions of the students' artistic accomplishment to conduct a comprehensive upgrade.

Design course is a concrete embodiment of students' creative ability. Art design courses cover a wide range, including clothing design, environmental design, interior design, media design, advertising design, and other different categories. With the rapid development of China's economic society, the heat of art and design has expanded from the school education to the market teaching. However, under the influence of various values, the deepening reform of art design education curriculum in our country lags behind the development speed of discipline itself.

\section{The Relationship between Art Design and Literary}

In the improvement of the concept of art design in China, the level of art and design reflects a country's economic and cultural status. Which contains the artistic level and design concepts are also constantly enhanced. In the promotion of the national economy, the innovation of art design needs and good cultural concept together, enhance the consumer's aesthetic consciousness and cultural responsibility.

For the art and design professional, to increase the students' literary accomplishment to enable students to deepen their artistic feelings, to meet their spiritual and spiritual values of cultural products. Only to reach a conscious, creative design concept, in order to form, color, structure to achieve mutual integration. For the community transport a large number of high-quality, all-round, 
three-dimensional high-level talent. To promote the aesthetic quality of students and cultural qualities of each other to enhance the artistic design of students of ideological consciousness and professional ability.

\section{The Necessity of Increasing Literary Accomplishment in Art Design Specialty}

As we all know, to enhance the students' literary accomplishment requires a wide range of development and development. On the whole, the literacy of students, including ideological literacy, cultural literacy, psychological literacy and so on. Literature literacy is the core of the development of art design students, only with high quality cultural level, can the theoretical knowledge and practical experience together to increase the impact of traditional culture on art and design.

\subsection{Literary accomplishment determines the aesthetic value of art and design}

Engels, a great thinker once said: "Each age of philosophy has its own specific areas of development, the need to have the characteristics of the ideological premise." Good literary accomplishment to achieve the ideological and artistic design, practicality and aesthetics, to enable designers to feel the value of literature contained in the ideas and depth.

In the process of art design, literary accomplishment under the guidance of the values of the formation of a different development trend. Art and Design students in the shaping of literary accomplishment, to achieve the depth of the traditional return to modern, so that the designer's way of thinking more depth, and enhance the audience's art design decisions and ideas. In the development area of modern art design, the service of art design course needs to meet the development condition of market economy, and also need to meet the public's psychological needs. Modern art education philosophy advocated by the art curriculum is a scientific design. The broad masses of art designers need to have a positive and healthy aesthetic taste, in the works of the deep penetration of cultural heritage, in order to be able to art design of the internal meaning of the details to change the concept of art education, tap the artistic value of art, art design teaching and The Fusion of Literary.

\subsection{Literary accomplishment affects the form of art design}

The cultural characteristic of art design is a kind of gradual development form. Whether it is cultural quality or art design, need to adapt to the development needs of the times, at different stages of development showing a different form of expression. For example, the development of literary style from the single began to change toward diversity, and artistic design style is also with the development of the times, from classical style to modernism forward, so that the designer's creative inspiration can be excited to form a rich Design concepts, in the creation of works of art in the process of expression.

From the integration of artistic design and literary accomplishment, the types of art need to have the corresponding value. To this end, the design students need to continue to accumulate literary accomplishment, to maintain the balance of development, symmetry, harmony, to achieve the art of design ideas and rhythm.

\subsection{Literary accomplishment to promote the depth of the ideological and artistic design}

The inner thought of literary accomplishment is the source of development of Chinese design culture and the foundation of the development of Chinese art design culture. The development of cultural traditions do not have the entity, its existence and cultural thought, is an abstract knowledge accumulation. The cultivation of literary accomplishment can further strengthen the artistic expression form, make the designer feel better the traditional culture and characteristic.

Influenced by the traditional culture, the Chinese people generally have the characteristic of loving elegance and respecting quiet development. This thought was influenced by the traditional thought of Laozi and Zhuangzi. Therefore, when designing this style, the designers should follow the creative idea of "the elephant invisible" in the traditional culture, integrate the Chinese classical aesthetic consciousness into the artistic design, and break up and enrich the Chinese aesthetic tradition and aesthetic value. In the overall consciousness, ecological meaning, human consciousness, a number of 
inspiration and guidance.

The shaping of Chinese traditional culture is the precipitation and accumulation of the Chinese nation for five thousand years, which further forms the foundation of the development of national culture. Objectively speaking, China's design field in the world is lagging behind, so the need for literary accomplishment and artistic design together, for the modernization of China's important guide.

\subsection{Literary accomplishment to create a creative situation in art and design}

Under the current situation, whether in the literary concept or in the design concept, we need to achieve "design re-creation", so that the design of students to be fully developed. In the cultivation of literary literacy, the construction of moral and intellectual beauty of students runs through the development. Students can be encouraged to read the "aesthetic appreciation", "Ordinary World" and other literary strong articles for the development of students power. At the same time in the process of the implementation of art and design education, to further expand the teaching resources, art and design of decorative beauty and literary accomplishment together, so that students of design awareness are fully inspire.

From the traditional design learning to break out on the drawbacks, and guide students in the ideas and methods of continuous innovation in the accumulation of literary literacy on the basis of the design work so that students understand the existing ideas to further enhance the cultural awareness of students, inheritance and innovation ability. For example, the Chinese traditional moral literature, plum, chrysanthemum, bamboo and other plants represent the pure, noble, cold thinking. Therefore, in the design activities, designers can use these representative works, for art and design into a more profound concept, to promote the appearance and inner work, culture and art design of the combination. In the cultural meaning of deconstruction on the deepening of cultural conservation, to provide a rich and varied design content and subject matter.

\section{Summary}

In summary, in art design, the cultivation of literary accomplishment need to help a variety of development strategies, deepen the designer's cultural awareness and literary depth. To further improve people's living standards. Change the cultural environment and cultural atmosphere of mutual integration, to deepen students' familiarity with literary works, art and literature will penetrate each other to enhance the art and design professional culture, so that the development of art disciplines can be more smooth. As the saying goes: "the book has its own gold house, the book has its own Yan Ruyu," through cultural traditions and artistic design of mutual integration, to expand the designer's way of thinking and enhance the behavior of students of design quality, is the designer in the works In the emotional expression, precipitation out of a more lucrative cultural industry value. So that the aesthetic elements of artistic design and literary knowledge are integrated with each other, giving the design work more profound thinking and value

\section{References}

[1] Yan Ming. Art education from figurative to abstraction [J]. Journal of Changsha University, 2015 (04).

[2] Li Yanzu. Introduction to Art Design [M]. Wuhan: Hubei Fine Arts Publishing House, 2013

[3] Long Yunfei, on the art and design education in the creative thinking [J], education reform, 2015 (09).

[4] Yao Wenbing, on aesthetic education and professional beauty of the shape of the United States [J], Journal of Anhui University of Technology, 2012 (19). 